\title{
30 Ekim 2020 Sisam Depreminin İzmir-Bayraklı'da Yol Açtığı Hasar Üzerinde Bornova Ovasının Alüvyal Jeomorfolojisinin Etkileri
}

\section{Effects of the Alluvial Geomorphology on the Damage of the Sisam Earthquake in the Bornova Plain}

\author{
Aylin KARADAŞ ${ }^{1} \oplus$, Ertuğ ÖNER ${ }^{2}$ (อ)
}

${ }^{1}$ Dr. Öğr. Üyesi, Ege Üniversitesi, Edebiyat Fakültesi Coğrafya Bölümü, İzmir, Türkiye

${ }^{2}$ Prof. Dr., Ege Üniversitesi, Edebiyat Fakültesi Coğrafya Bölümü, İzmir, Türkiye

ORCID: A.K. 0000-0002-3845-3246; E.Ö. 0000-0002-9712-5277

\section{Öz}

Bu çalışmada 30 Ekim 2020 günü merkez üssü Kuşadası Körfezi olan Sisam Depremi nedeniyle Bornova Ovası üstündeki yerleşim alanlarında meydana gelen yıkım ve hasarın dağılışında Bornova Ovası'nı oluşturan alüvyonların etkilerinin değerlendirilmesi amaçlanmışıı. Bu amaçla hasar durumunun dağılışını belirlemek için Çevre ve Şehircilik Bakanlığına ait adrese dayalı hasar tespit verileri kullanılmıştır. Hasar dağısşı ile ovayı oluşturan alüvyonların özelliklerinin ilişkilendirilmesi için Bornova Ovası́nı oluşturan alüvyonların sedimantolojik ve stratigrafik özelliklerini delgi sondaj yöntemi ile ortaya koyan önceki çalışmalardan yararlanıımıştır. Çalışmada hasarlı binaların konumları uydu görüntüsü ve sedimantolojik-stratigrafik kesitler üzerine aktarılmıştır. Önceki çalışmalarda sunulan Bornova Ovası kıyı bölümünde yapılan alüvyal delgi sondajlara ait sedimantolojik-stratigrafik veriler ile hasar durumu ilişkilendirilmiştir. Sonuç olarak depremden en fazla hasar alan binaların Holosen transgresyonuna bağlı olarak kısa mesafeler içerisinde alüvyonların niteliğinde değişimlerin görüldüğü alçak ova tabanında yoğunlaştığı izlenmiştir. Nitekim yıkılan 7 binanın 6'sı ve hasar alan binaların çoğunluğu bu değişimlerin gözlendiği Holosen transgresyonunun etki alanı üzerindedir. Özellikle son yıllarda Bornova Ovası'nın hemen kıyı gerisindeki bu alanın çok yüksek katlı binaların inşa edildiği bir bölgeye dönüşmesi olası depremler açııından tehlike ve riskleri artırmaktadır. Bu açıdan Bornova Ovası dâhil körfezi çevreleyen alüvyal alanları oluşturan alüvyonların özelliklerinin ve olası bir depreme karşı gösterecekleri tepkilerin belirlenmesi önem taşımaktadır.

Anahtar kelimeler: 30 Ekim 2020 Sisam Depremi, Bornova Ovası, Alüvyal Jeomorfoloji

\section{ABSTRACT}

On October 30, 2020, an earthquake struck the offshore region of the north of Samos Island, in the Gulf of Kuşadası with a magnitude of 6.9. According to damage reports, Bayrakli and Bornova districts were the most affected areas by the earthquake based on the extent of damage and loss. This study aims to evaluate the effects of alluvial properties of the Bornova Plain on the distribution of earthquake damage. The address-based damage reports of the Ministry of Environment and Urbanization and findings of previous studies on the alluvial characteristics of the Bornova Plain were used to interpret the damage distribution. In the study, the damaged building locations were transferred on satellite images and sedimentological-stratigraphic cross-sections. The sedimentological-stratigraphic data of the nine core drillings made in the coastal part of the Bornova Plain presented in the previous studies were associated with the earthquake damage. Alluvial changes related to the Holocene transgression in alluvial stratigraphy present various conditions by means of durability. Six of the collapsed buildings and most of the damaged buildings are located in the mid-Holocene transgression area. In recent years, as an urban renewal area, this field has turned into an area of high-rise apartment blocks and towers. Such change may increase the possibility of earthquake risks. In this regard, it is important to determine the characteristics of the alluviums that form in the alluvial areas surrounding the Izmir bay.

Keywords: 30 October 2020 Samos Earthquake, Bornova Plain, Alluvial Geomorphology

Başvuru/Submitted: 02.02.2021 • Revizyon Talebi/Revision Requested: 29.03.2021 • Son Revizyon/Last Revision Received: 14.04 .2021 • Kabul/Accepted: 20.04 .2021

Sorumlu yazar/Corresponding author: Aylin KARADAŞ / aylin.karadas@ege.edu.tr

Atıf/Citation: Karadas, A., \& Oner, E. (2021). 30 Ekim 2020 Sisam depreminin İzmir-Bayraklı'da yol açtığı hasar üzerinde Bornova Ovasının alüvyal jeomorfolojisinin etkileri. Cografya Dergisi, 42, 139-153. https://doi.org/10.26650/JGEOG2021-872890 


\section{EXTENDED ABSTRACT}

On October 30, 2020, at 14:51 hours, an earthquake with a magnitude of 6.9 struck the offshore region of the north of Samos Island in the Gulf of Kuşadası. The mainshock of earthquake occurred on a $30 \mathrm{~km}$ east-west trending normal fault passing through the north of the island. Its magnitude was recorded as equivalent to one of the major earthquakes in the region. The duration of the earthquake was 15.68 seconds, and it was followed by 5,799 aftershocks (magnitude 0.7-5.1) in the next two months. The epicenter of the earthquake is approximately $10 \mathrm{~km}$ away from the north coast of the Samos Island. The nearest place to the epicenter in Turkey is $27 \mathrm{~km}$ away in Seferihisar.

Due to the 6.9 magnitude earthquake, loss of life, injuries, building collapses, and damages occurred. Two fatalities and 19 injuries were reported on the Samos island, which is the closest to the earthquake epicenter. In contrast, the Bayrakl1 and Bornova districts of the İzmir province, which is $70 \mathrm{~km}$ away from the epicenter, are the most affected places regarding the number of damages and losses. The Bornova Plain is a densely populated residential area of Bornova and Bayraklı. During the earthquake, seven buildings completely collapsed, 117 people lost their lives, and 1,035 injuries occurred. Additionally, various other damaged buildings were reported.

The damage distribution caused by the Samos earthquake shows that all the collapsed and severely destroyed buildings are clustered in a particular area. It is striking that the buildings damaged and collapsed by the earthquake in the Bayraklı and Bornova districts, show an intense distribution on the lower plain, gathered between the İzmir bay and the Çanakkale motorway, north of Ankara Street. This place is the settlement area of Adalet, Manavkuyu, and Mansuroğlu neighborhoods of the Bayraklı district and Kazım Dirik of Bornova. The collapsed buildings with a high number of fatalities_Emrah Apartment, Riza Bey Apartment, Doğanlar Apartment, Y1lmaz Erbek Apartment, Yağcılar Apartment, Barış Apartment, and Cumhuriyet Apartment—are located here.

The fact that the collapsed and heavily damaged buildings are located close to each other might be related to the characteristics of the alluvium forming the plain. In this study, the distribution of the earthquake damage occurred in the Bornova Plain and the alluvial characteristics forming the plain are evaluated.

The stratigraphic and sedimentological characteristics of alluvial deposits in the lower plain are affected by the changes in paleogeography during Holocene. The effects of Holocene transgression on the formation of the lower Bornova Plain are important. In this part of the plain, environmental changes due to transgression caused facies diversity in alluvial stratigraphy. Facies changes present different durability conditions. In fact, six of the collapsed buildings and many damaged buildings are located in the mid-Holocene transgression area. Here alternating marine sediments, of the sandy-silty grain size, result in loose and loamy properties, which is considered poor ground in terms of construction suitability. Due to the alluvial properties of the Bornova Plain, it is open to effects such as lateral spreading, liquefaction, and possible site amplification. In contrast, morphographic features of the Bornova Plain must have increased the basin effect during the earthquake. In that, the Bornova Plain is a small tectonic depression as a part of the horst-graben system of Western Anatolia. This plain is controlled by the İzmir Fault and the Karşıyaka Fault. The plain is surrounded by relatively hard and resistant Tertiary volcanics and Mesozoic basement rocks. These characteristics suggest that basin effects may have increased around the Adalet, Manavkuyu, and Mansuroğlu neighborhoods. Thus, the seismic waves spreading from the Kuşadası Bay must have lingered on the clastic material (alluvial, colluvial, and marine sediments) of the Bornova Plain reaching hundreds of meters' thickness. 


\section{GíRiş}

Sisam Depremi, 30 Ekim 2020 günü saat 14:51 de Ege Denizi'nde Kuşadası Körfezi açıklarında Sisam Adası'nın kuzeyinde meydana gelmiştir. Deprem, adanın kuzeyinden geçen doğu-batı uzanıml $30 \mathrm{~km}$ uzunluğundaki normal atımlı bir fay üzerinde gerçekleşmiştir. Büyüklük ve etkileri bakımından bulunduğu bölge açısından son yüzyılın en büyük depremlerinden birisi olarak kayıtlara geçmiştir (Şekil 1). Söz edilen bu depremin ardından ulusal ve uluslararası deprem izleme merkezlerinden depremin büyüklüğü ile ilgili veriler sunulmuştur. Depremin büyüklüğü KOERİ (Kandilli Rasathanesi ve Deprem Araştırma Enstitüsü)'ne göre Mw 6.9, AFAD (Afet ve Acil Durum Yönetimi Başkanlığı Deprem Dairesi Başkanlığı)'na göre Mw 6.6, GFZ (Alman Yer Bilimleri Araştırma Merkezi)'ne göre Mw 7.0, OCA (GéoAzur Gözlem Merkezi)'ne göre ise Mw: 7.2 olarak bildirilmiştir (Sözbilir vd.2020, AFAD, 2020).

AFAD verilerine göre depremin derinliği $15 \mathrm{~km}$ 'dir. Depremin süresi 15,68 sn olarak ölçülmüş; şiddeti ise merkez üssünde VIII olarak hesaplanmıştır. Deprem kayıtlarına göre depremin ana şokundan sonra da bölgedeki 3 fay üzerinde aktivite ve enerji boşalımları olmuştur. Arţ̧ı depremler devam etmiş ve ilk 2 ay (62 gün) içinde büyüklüğü $0,7-5,1$ arasında değişen 5799 artçı deprem kaydedilmiştir (AFAD, 2020; METU/EERC, 2020).
Sisam Adası'na oldukça yakın konumu nedeniyle Sisam Depremi olarak anılan bu depremin Türkiye kiyılarına olan mesafesi, en yakın olduğu İzmir- Seferihisar'a, $27 \mathrm{~km}$ dir. Türkiye'nin Ege Denizi kıyılarına yakın konumu nedeniyle deprem, Batı Anadolu'dan (İzmir, Aydın, Manisa, Balıkesir, Denizli, Muğla) Marmara kıyılarında İstanbul'a kadar hissedilmiştir.

Kandilli Rasathanesi kayıtlarına göre 6,9 büyüklüğünde gerçekleşen bu depremde can kayıpları, yıkılan binalar ve yapı hasarları olmuştur. Deprem sonrasına ait hasar kayıtları ve can kayıplarına göre, depremin merkez üssüne en yakın yerleşim alanı olan Sisam Adası'nda 2 can kaybı ve 19 yaralı bildirilmiştir (Günay vd., 2020; Papadimitriou vd,, 2020).

Öte yandan, deprem sonrasında rapor edilen can kaybı ve hasar durumu açısından, en çok etkilenen bölge merkez üssüne $70 \mathrm{~km}$ uzaklıkta yer alan İzmir ilinin Bayraklı ve Bornova ilçeleri olmuştur. Söz konusu ilçelerde hasarın yoğunlaştığı alan ise Bornova Ovası'dır. Bornova Ovası, Bayraklı ve Bornova ilçelerinin yüksek katlı binaları ile yoğun nüfuslanmış yerleşim alanıdır. İzmir Valiliği ve AFAD verilerine göre, Sisam depremi sonrasında Bornova Ovası'nda 7 bina tamamen yıkılmış; birçok bina farklı düzeylerde hasar almıştır (Şekil 2). Yıkılan binalarda 117 kişinin yaşamını kaybettiği ve 1035 kişinin de yaralandığı rapor edilmiştir

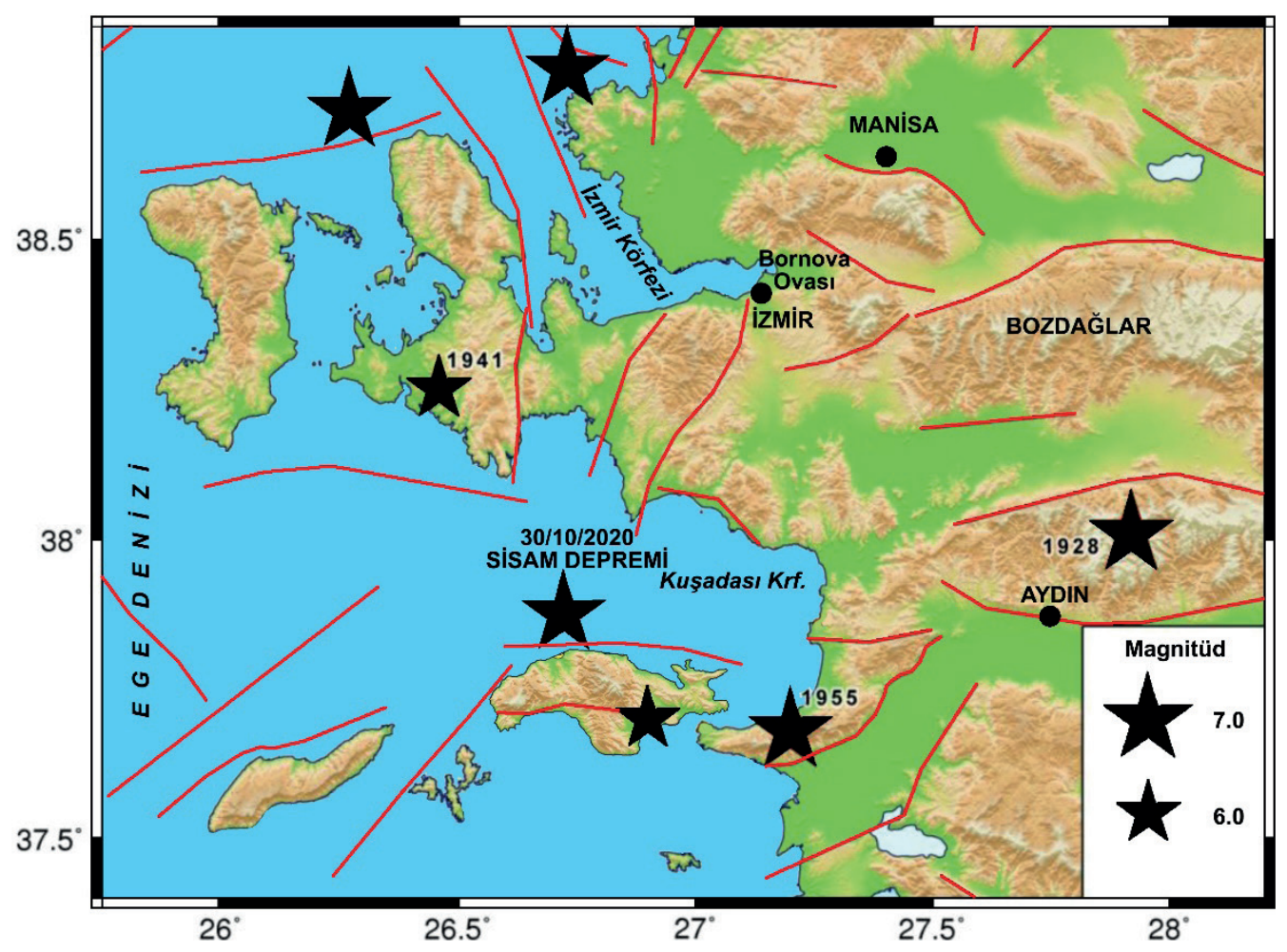

Şekil 1: Aletsel dönemde İzmir ve çevresinde meydana gelmiş magnütüdü 6 ve daha büyük depremlerin dağılışı (Papadimitriou vd., 2020'den). Figure 1: The distribution of major earthquakes of magnitude 6 and greater in Izmir and surroundings in instrumental period (Papadimitriou vd., 2020). 

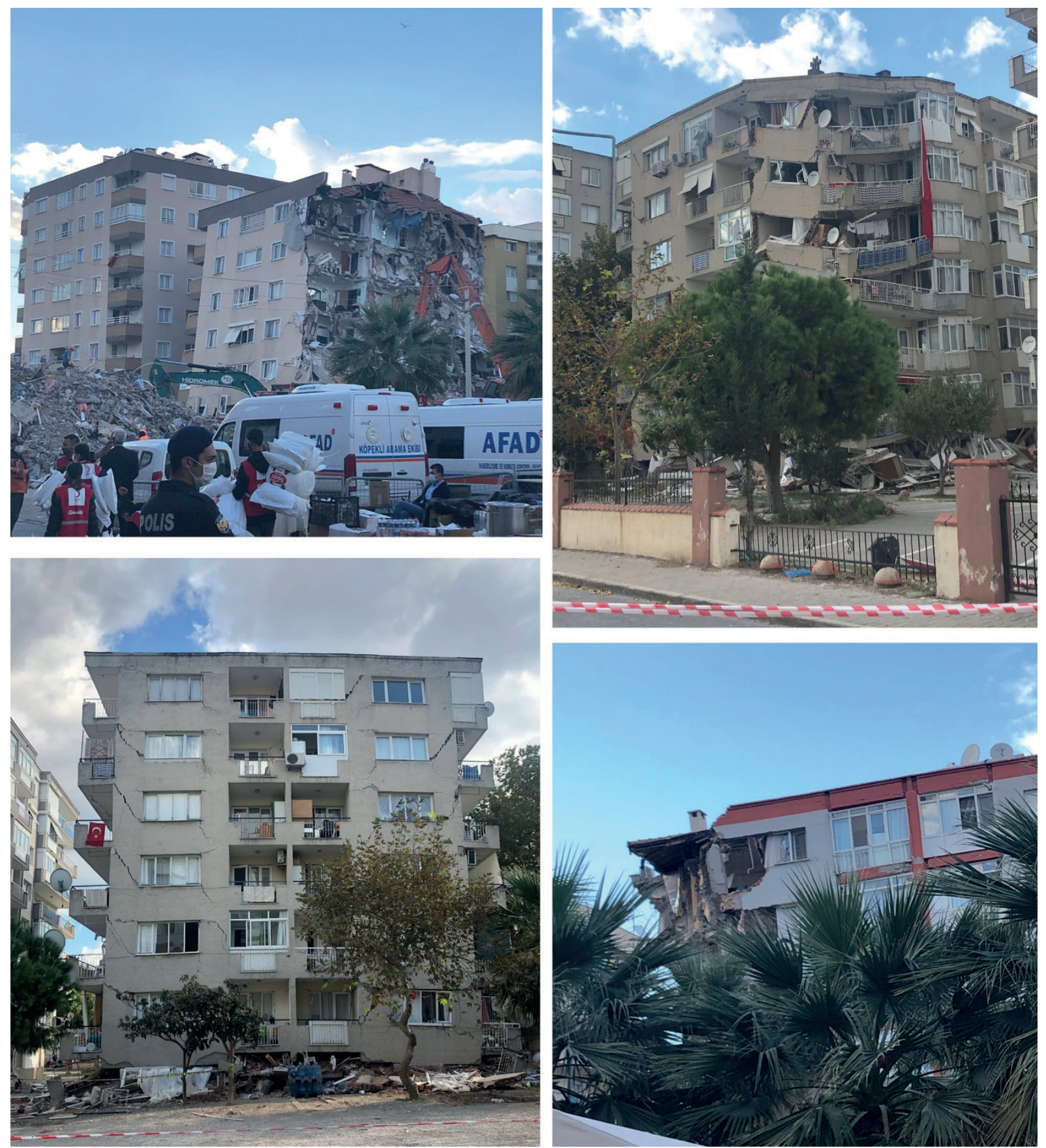

Şekil 2: Bornova Ovası'nda deprem sırasında ağır hasar alan binalardan fotoğraflar.

Figure 2: Pictures of some of the buildings got damaged during Samos Earthquake.

(AFAD, 2020). Hasar kayıtlarına dayalı olarak depremin en çok hissedildiği İzmir çevresinde depremin şiddeti VII olarak hesaplanmıştır (Sözbilir vd., 2020). Sisam depremi sonrasında depremden en büyük hasarla etkilenen il olan İzmir'de T.C. Çevre ve Şehircilik Bakanlığı'nın 195.000 bina üzerinde yaptığı değerlendirmesine göre, büyük bölümü Bornova Ovası'nda yer alan 652 bina ağır hasarlı, 778 bina orta hasarlı ve 5000 in üzerinde bina hafif hasarlı olarak açıklanmıştır. Bunların dışında 71 bina acil yıkılacak olarak belirlenmiştir (Toprakçı ve Ekizler, 2020).

\section{1. Önceki Çalışmalar}

Türkiye, I. Derecede deprem bölgesi içinde yer alması dolayısıyla zaman zaman büyük depremler ile sarsılan bir ülkedir. Tektonik konumundan kaynaklı yer kabuğu hareketliliği nedeniyle bazı bölgelerde depremlerin frekansları ve büyüklükleri daha fazla olmaktadır. Böyle bölgelerde büyük yerşekli blokları ile çevrili ova tabanlarında depremlerin şiddeti ve etkileri de daha fazla gerçekleşmektedir. Özellikle alüvyal ova tabanlarında pekişmemiş, 
gevşek tanelerin tekstür, strüktür ve nemlilik gibi özellikleri depremlerin sebep olduğu hasarı artırmaktadır (Tablo 1). Nitekim depremlerin şiddeti ve hasar derecesinin dağılışı ile deprem dalgalarına karşı davranışları bakımından farklılık gösteren zeminler arasında önemli ilişkiler bulunduğu öteden beri bilinmektedir. $\mathrm{Bu}$ ilişkiler ülkemizde meydana gelen büyük depremlerde de etkili rol oynamış, bir yandan deprem şiddetini arttırmak, diğer yandan da tektonik yapı ve inşaat kalitesi ile açıklanamayan şiddet ve hasar dağılışlarına yol açarak etki göstermiştir (Erinç, Bener, Sungur ve Göçmen, 1971).

Günümüze kadar ülkemizde gerçekleşen büyük depremlerin sebep olduğu hasar durumu ile yapı-zemin özelliklerini ilişkilendiren çeşitli coğrafi çalışmalar yapılmıştır. Örneğin 1970 Gediz depremi sonrasında Erinç vd. (1970) tarafindan yapılan çalışmada zemin ve hasar durumu değerlendirilmiş; özellikle çukur, suya doygun alüvyal alanlarda ve yüksek plastisite gösteren killi Neojen formasyonları üzerinde deprem şiddetinin arttı̆̆ 1 ve hasarın çok fazla olduğu ifade edilmiştir. Erinç vd. (1971) Burdur depremi sonrasında hasar-zemin ilişkilerini değerlendirdiği çalışmasında Burdur depremi sırasında meydana gelen hasar üzerinde zemine ait özelliklerin belirleyici olduğu, hasarın Holosen yaşlı taraça dolguları ve suya doygun alüvyonlar üzerinde yoğunlaştığını belirtmektedir. Büyüklüğü açısından Türkiye'de son yüzyılda gerçekleşen en büyük depremler arasında yer alan 17 Ağustos 1999 Adapazarı depremi, yol açttğı can kaybı ve hasar durumu açısından da şiddetli depremler arasındadır. Turoğlu (2004) Adapazarı depremine bağlı zemin sıvılaşması ve hasar derecelerini ilişkilendirdiği çalışmasında sarsıntı ve sıvılaşmanın neden olduğu hasar gruplarını belirlemiş ve Adapazarı çevresinde hasar dağılışını jeomorfolojik birimler ile ilişkilendirmiş ve hasarlı yapıların ova tabanında yoğunlaştı̆̆ını ifade etmiştir.

Yukarıda örnekleri verilen çalışmalarda da belirtildiği gibi alüvyal alanların zemin özelliği açısından deprem sırasındaki davranışları, depremin şiddetini ve etkisini büyütmek suretiyle hasar ve kayıp durumunu artırmaktadır. Dahası, alüvyal alanların kendi içindeki ortam özelliklerindeki değişmeler bile depremlerin yıkıcı etkileri üzerinde belirleyici olmaktadır. Tane boyu, fasiyes, su muhteviyatı gibi özellikler aynı bölgede farklı hasar derecelerinin ortaya çıkmasını sonuçlandırmaktadır. Bu çalışmada önceki çalışmalardan farklı olarak deprem hasar dağılışı ile alüvyal alanı oluşturan alüvyonların sözü edilen özellikleri ilişkilendirilmiştir.

\subsection{Amaç, Materyal ve Yöntem}

Sisamdepreminhissedildiğitümbölgelerdeğerlendirildiğinde, deprem sırasında göçen binaların tümünün Bornova Ovası'nda yer alması, özellikle de yıkılan ve ağır hasar alan binaların ovanın belli bir bölümünde yoğunlaşması dikkat çekicidir.

Depremin merkez üssüne uzak bir konumda olmasına rağmen, Bornova Ovası'nın depremden en çok etkilenen yer olmasının nedenleri kuşkusuz çok boyutlu - multidisipliner bir araştırma konusudur. Şöyle ki, depremlerin yüzeyde sebep olduğu yıkıcı etkilerini belirleyen çeşitli parametreler bulunur. Bunlar arasında, meydana gelen depreme ait özellikler (depremin büyüklüğü, derinliği, merkez üssüne uzaklık vb.), yapılara ait kusurlar (yapı malzemesi, tasarımı ve tekniği vb.) ve yapıların kullanımı ile ilgili hatalar son derece önemlidir. Öte yandan zemine ait özellikler (litoloji, suya doygunluk vb.) depremlerin etkisi üzerinde başlı başına etkili bir unsurdur. Nitekim zeminin deprem sırasındaki davranışı zeminde oturma, göçme ya da sıvılaşma yoluyla yapılar üzerinde hasar ve yıkıma sebep olan durumlar ortaya çıkarmaktadır. Bu çalışmada Sisam Depremi sırasında Bornova Ovası'nda hasar alan binaların dağılışı ile ovayı oluşturan alüvyonların özelliklerinin ilişkilendirilmesi amaçlanmıştır.

Çalışma kapsamında, Sisam depremi sonrasında T.C. Çevre ve Şehircilik Bakanlı̆̆ı'nın yayınladığı adrese dayalı İzmir

Tablo 1: Jeomorfolojik birimler ve sismik yer hareketleri kaynaklı sıvılaşma etkisi (Turoğlu, 2004).

Table 1: Geomorphological units and liquefaction effect caused by seismic movements.

\begin{tabular}{ll}
\hline Jeomorfolojik birimler & Yer sarsıntısından sıvılaşma olasılığı \\
\hline Plato yüzeyi & Yok \\
Yamaçlar (Anakaya) & Yok \\
Yamaç depoları, Birikinti konileri & Genel olarak düşük, ancak yeraltı suyu seviyesine göre bazı derecelerde mevcuttur. \\
Kademe düzlükleri & Yok \\
Vadi tabanları ve taraçalar & Lokal yayılımlar için etkili \\
Akarsu leveleri & Belli oranlarda etkili \\
Art bataklık sahaları & Lokal yayılımlar için etkili \\
Bataklık ve killi depolar & Yüksek \\
Terk edilmiş akarsu yatakları & Yüksek \\
Kum çökelleri & Genel olarak düşük \\
Yapay ve sığ deniz dolgu alanları & Yüksek \\
\hline
\end{tabular}


Depremi Hasar Tespit Çalışmalarında elde edilen verilerden yararlanılmıştır. Sözü edilen veriler mahalle bazında olup Yıkık, Acil Yıkılacak, Ağır Hasarlı, Orta Hasarlı, Hafif Hasarlı ve Hasarsız olarak 6 sinıfta kategorize olarak sunulmaktadır. Bu hasar sinıfları arasından Hafif Hasarlı binalar bölgesel olarak sayıca çok olduğu ve bir kümelenme göstermediği için çalışma kapsamı dışında tutulmuştur.

Bu çalışma kapsamında Bayraklı ilçesinden Adalet, Bayraklı, Çiçek, Manavkuyu, Mansuroğlu, Osmangazi, Soğukkuyu ve Tepekule mahalleleri; Bornova ilçesinden Atatürk, Barbaros, Birlik, Çamkule, Çınar, Doğanlar, Egemenlik, Ergene, Erzene, Evka 3, Evka 4, Gaziosmanpaşa, Gürpınar, İnönü, Karacaoğlan, Kazımdirik, Kemalpaşa, Kızılay, Koşukavak, Meriç, Merkez, Mevlana, Rafetpaşa, Serintepe, Tuna, Ümit, Yeşilova, Yıldırım Beyazıt ve Yunus Emre mahallerine ait deprem hasar kayıtları kullanılmıştır.

Deprem hasarının ovanın alüvyal özellikleri ile ilişkilendirilmesi için Bornova Ovası'nı oluşturan alüvyonların stratigrafik ve sedimantolojik özelliklerini ortaya koyan önceki çalışmalardan yararlanılmıştır (Karadaş, 2012; Karadaş, 2014). Sözü edilen bu çalışmalarda Bornova Ovası'nın alçak ova tabanında derinliği 11-19 metre arasında değişen 9 adet karotlu alüvyon sondajı yapılmış bu sondajlara ait veriler sunulmuştur.

Çalışmada yukarıda belirtilen mahallere ait hasarlı bina adres bilgileri gerçek konumlarıyla güncel bir uydu görüntüsü üzerine aktarılmıştır. Ayrıca hasar durumunun belirlenmesinde arazi gözlemleri yapılmış ve ağır hasar alan binaların konum bilgileri alınarak fotoğraflanmıştır (Şekil 2). Ardından, deprem sırasında yıkılan binaların hasar tespit verilerinden ve arazi gözlemlerinden elde edilen konum bilgileri, önceki çalışmalarda ortaya konulan Bornova Ovası'na ait doğu-batı ve kuzey-güney yönlü stratigrafik-paleocoğrafik kesitler üzerine eklenerek alüvyal jeomorfolojik özelikler ile hasar dağılımı ilişkilendirilmiştir.

\section{YAPISAL - JEOMORFOLOJIK ÖZELLIKKLER}

Bornova Ovası, İzmir Körfezi’nin doğu bölümünde yer alan yaklaş1k $50 \mathrm{~km}^{2}$ büyüklüğü ile nispeten küçük bir düzlüktür. Ova, doğu-batı doğrultusunda uzanan tektonik bir çukurluk içinde şekillenmiştir. Bornova Ovası, kuzeyinde Yamanlar Dağı (1076 m), güneydoğusunda Kemalpaşa Dağı (1506 m), güneyinde Kalabak Tepe (379 m) ve doğu bölümünde Belkahve Eşiği (500 m) ile sınırlanır (Şekil 3). Bu eşik ile Bornova Ovası Kemalpaşa Ovası'ndan ayrılır.

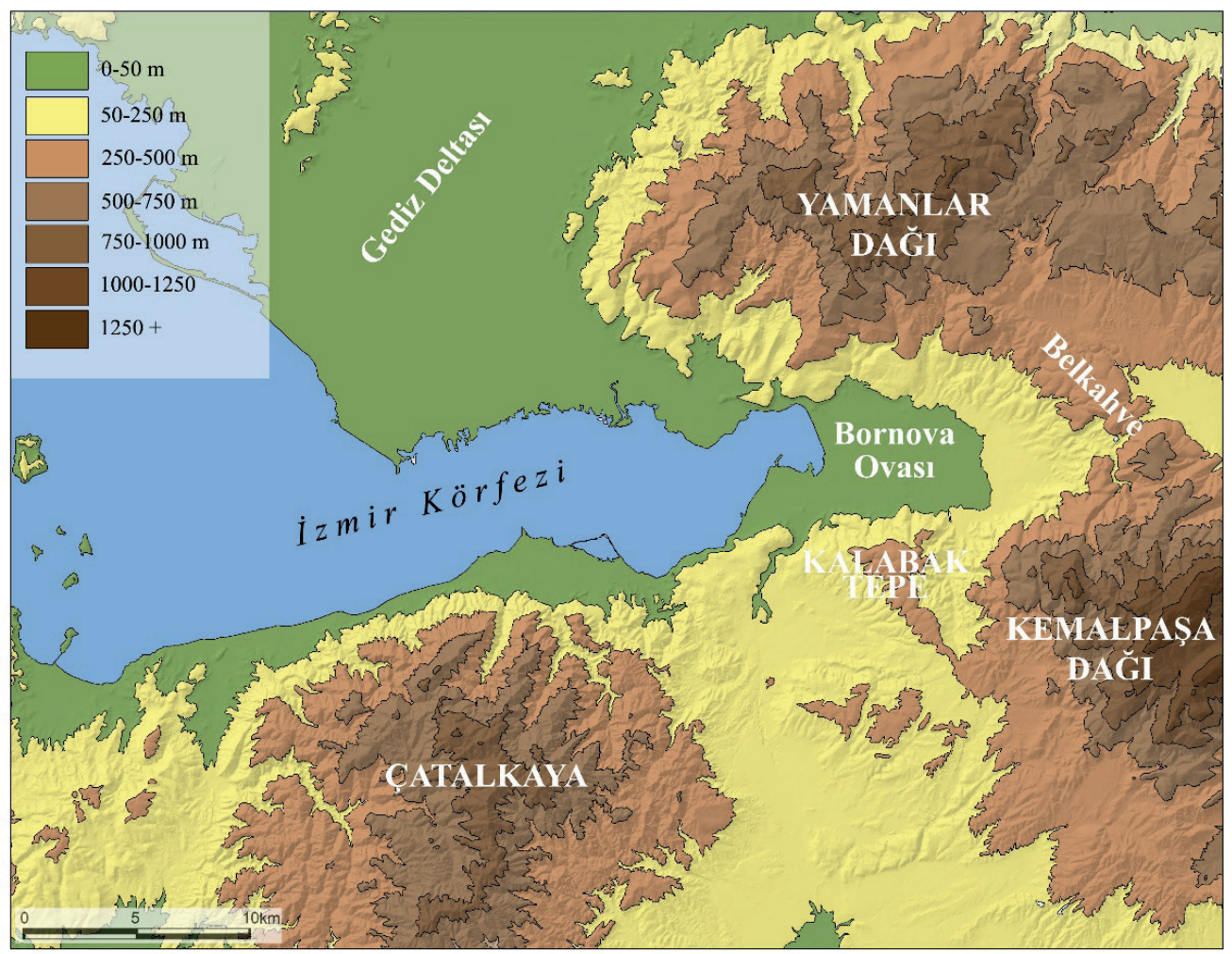

Şekil 3: Bornova Ovası'nı çevreleyen yükselti basamakları haritası.

Figure 3: Elevation levels map of Bornova Plain and surroundings. 
Bornova Ovası, çevresindeki Yamanlar Dağı ve Kemalpaşa dağı gibi yüksek rölyeften ovaya ulaşan kısa boylu ve mevsimlik akışlı dağ derelerinin getirdiği alüvyonların bu tektonik kökenli çukurluğu doldurmasıyla şekillenmiştir. Bunlardan kaynağını Yamanlar dağından alan Kocaçay ve kaynağını Kemalpaşa dağından alan Manda Çayı Bornova Ovası üzerinden İzmir Körfezi'ne dökülen en büyük akarsulardır. Çevresinde yükselen dağlık kütleler arasında küçük bir havza tabanı olan Bornova Ovası, bu yüksek dağlık ve tepelik alanların eteklerinde gelişmiş birikinti konileri ile çevrelenmektedir. Dağ derelerinin taşıdığ kaba taneli unsurlardan oluşan birikinti konileri, ova tabanı çevresinde bir kuşak oluşturur.

Bornova Ovası yapısal olarak Paleotektonik dönemde oluşmuş iki farklı birimin kesişme alanında, Anadolu'nun batı bölümünün temelini oluşturan Menderes masifinin kuzeyinde ve kuzeydoğu-güneybatı uzanımlı İzmir Ankara Zonu üzerinde yer alır. Bu Paleotektonik yapılar, Neotektonik dönemde Batı Anadolu'da etkili olan gerilme tektoniğinin bir sonucu olarak, doğu-batı doğrultusunda kırılmış ve üzerlerinde bugünkü horstgraben sistemi gelişmiştir. Gediz grabeninin bir kolu olarak bu sistemin bir parçası olan Bornova Ovası, İzmir Körfezi'nin doğusunda yer alan tektonik bir çukurluktur. Bu çukurluk / graben İzmir Körfezi açıklarından başlayıp doğuda Belkahve eşiğine kadar uzanmaktadır. Bornova Ovası'nı çevreleyen yüksek bloklar kuzeyde Yamanlar Dağı ve güneyde Kemalpaşa Dağ1 ile Kalabak Tepe'dir (Şekil 3). Bunlar Neotektonik dönemde gerilerek çeşitli doğrultularda gelişen faylanmalar ile yükselmiş̧ir.

Ovanın güneydoğusunda Kemalpaşa Dağı ve doğusunda Belkahve Eşiği yapısal olarak İzmir-Ankara Zonu içinde yer alır (Şekil 4). Bornova Karmaşığı'na (Geç Kretase-Paleosen) ait kayaçlar ovayı çevreleyen en yaşlı birimler olup bu formasyonun alt seviyeleri daha çok kırıntılı, üst seviyeleri karbonatlı tortullardan oluşmaktadır (Sözbilir vd., 2008; Sarı, 2018).

Ovayı çevreleyen alanda Bornova karmaşığına ait kayaçlar, Miyosen formasyonlar ile örtülmektedir. $\mathrm{Bu}$ formasyonlar, genellikle gölsel, kırıntılı ve karbonatlı birimlerden ve bu birimlerle birlikte yaşıt yaygın volkanik formasyonlardan oluşmaktadır (Şekil 4). Aglomera, tüf ve andezit-dasit lavlardan oluşan volkanik formasyonlar ovanın kuzeyinde yükselen Yamanlar Dağı'nın yapısını oluşturmaktadır (Akdeniz, Konak, Öztürk ve Çakır, 1986). Diğer yandan Miyosen yaşlı tortul formasyonlar Bornova Ovası güneyinde alçak tepelik rölyefe karşılık gelir. Ovanın güneyinde yer alan Kalabak Tepe ve Belkahve Eşiği'nin kuzey bölümlerindeki tepelik alanların yapısını Miyosen yaşlı gölsel konglomera, kumtaşı, marn, kiltaşı ve kireçtaşı oluşturmaktadır.

Geç Miyosen'den itibaren tüm Anadolu'yu etkileyen yeni tektonik koşullar daha önce de ifade edildiği gibi Batı Anadolu'da horst-graben sisteminin oluşması ile sonuçlanmıştır. Bu süreçte Yamanlar Dağı ve Kemalpaşa Dağı gibi yükselen bloklar arasında İzmir Körfezi - Bornova çukurluğu çökerek şekillenmiştir. Pliyosen ve Kuvaterner boyunca derinleşen bu tektonik oluğun tabanı karasal çökeller ile doldurulmuştur (Kayan, 2000, Öner ve Kayan, 2005). Günümüzde ovay1 çevreleyen birikinti koni ve yelpazelerinin kök bölümlerinde yüzeyde görülen Pliyosen-Pleyistosen dolgular Bornova ova tabanında 300 metreden kalın depolar oluşturmaktadır (Şekil 5). $\mathrm{Bu}$ karasal dolgular güncel flüvyal ve kolüvyal birimler ile örtülüdür.

Bornova Ova tabanı eğim koşulları ve alüvyon özellikleri açısından 2 bölüme ayrılır. Dağlık alanların eteklerinde, tabanın nispeten yüksek kesimlerinde birikinti koni ve yelpazeleri yer alır. Bu koniler dağlık alanlardan gelen küçük mevsimlik akarsuların taşıyıp biriktirdiği kaba taneli kolüvyal malzemeden yapılıdır. Bunlar Bornova Ovası'nın Yüksek Ova Tabanın oluştururlar (Şekil 6). Bornova Ovası'ndaki Koca Çay, Manda Çayı ve Gökdere gibi küçük akarsuların dağlık alanlardan ve özellikle bunların eteklerindeki birikinti konilerinden taşıdıkları nispeten ince tane boylu malzemelerden oluşan taşkın sedimanları ise Alçak Ova Tabanını oluşturmaktadır (Kayan, 2000) (Şekil 6).

Bornova Ovası'nın bugünkü görünümüne kavuşması Holosen'de gerçekleşmiştir. Bu dönemde ovanın kıyı bölümünde alüvyal şekillenme üzerinde deniz seviyesi değişiklikleri ve kıyı çizgisi değişmeleri etkili olmuştur. Şöyle ki, günümüzden 20 bin y1l önce son buzul maksimumunda (LGM) küresel ölçekte deniz seviyesinin güncel seviyesinden 130 metre alçakta bulunduğu bir çok çalışmada belirtilmektedir (Waelbroeck vd., 2002; Fleming vd., 1998; Peltier, 2002; Perissoratis ve Conispoliatis, 2003; Lambeck ve Purcell, 2005; Lambeck, Rouby, Purcell, Sun ve Sambridgea, 2014; Benjamin vd., 2017). Bu dönemden itibaren glasyo-östatik olarak deniz seviyesinin yükseldiği ve günümüzden 6000 yıl önce bugünkü seviyesine ulaştığ 1 belirlenmiştir (Fleming vd., 1998 ; Kayan, 1991 ; Kayan, 1997 ; Kayan, 1999 ; Kayan, 2012 ; Brückner, Vött, Schriver ve Handl, 2005 ; Brückner, Kelterbaum, Marunchak, Porotov ve Vött, 2010; Vardar, Öner, ve İlhan, 2017 ; Öner ve Vardar, 2018; Vardar, İlhan ve Öner 2020). Holosen Transgresyonu olarak adlandırılan bu olayla kıyı bölgelerinde akarsu vadileri ve alçak 


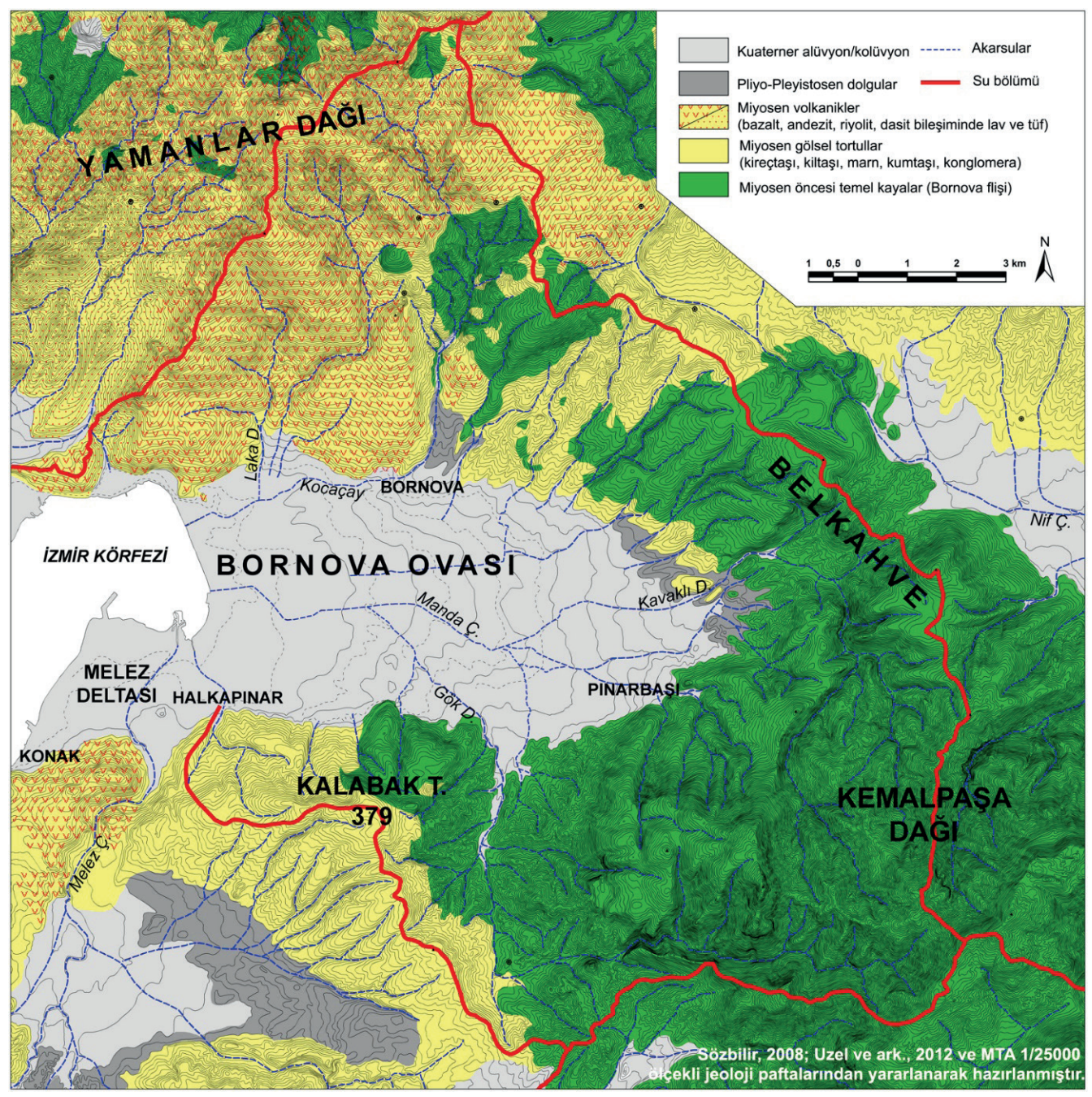

Şekil 4: Bornova Ovası ve çevresinin yapısal özellikleri (Karadaş 2012 s.252).

Figure 4: Main structural units around İzmir (Karadaş 2012, p.252).

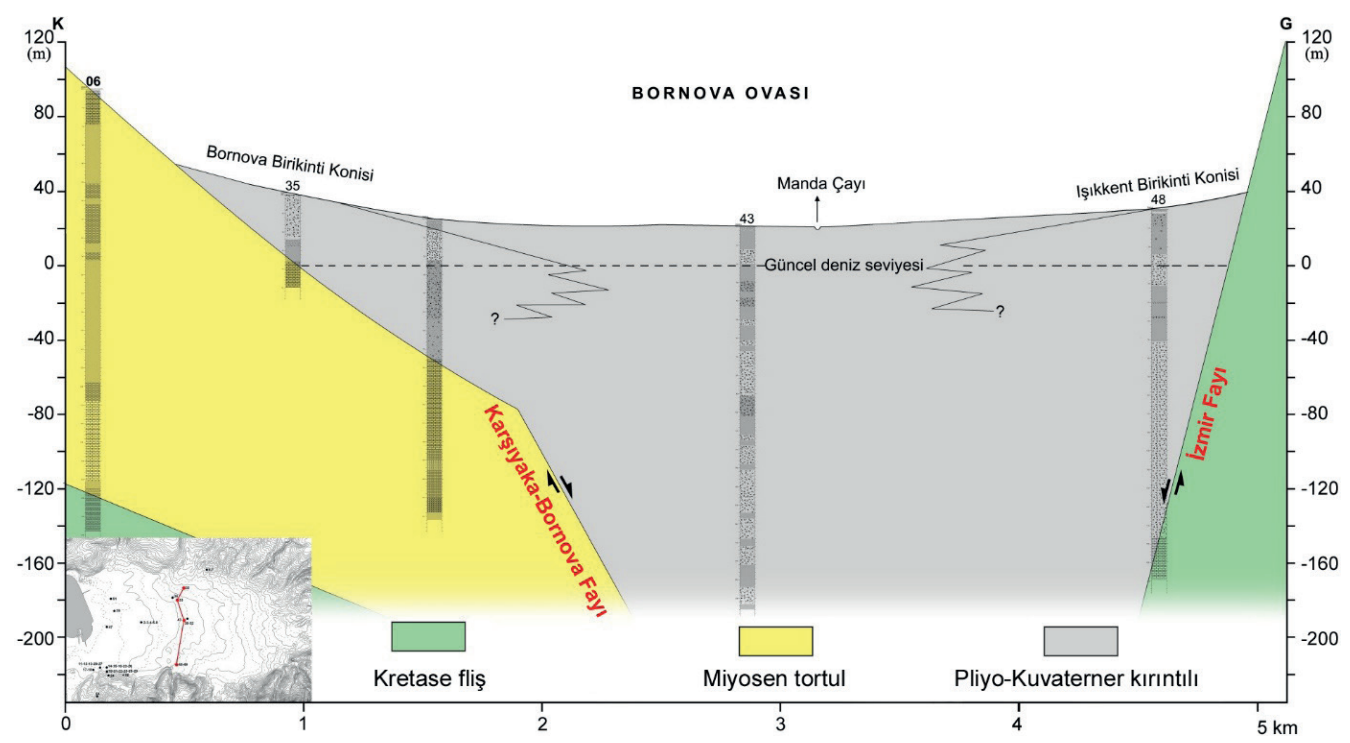

Şekil 5: DSi sondaj verilerine göre Bornova Ovası'nı oluşturan detritik dolguların kalınlığı ovanın orta bölümünde artmaktadır (Karadaş 2012, s.47).

Figure 5: The thickness of the detritic fillings in Bornova Plain increases in the middle part of the plain (according to State Hydraulic Works - DSI sediment core data), (Karadaş 2012,p.47). 


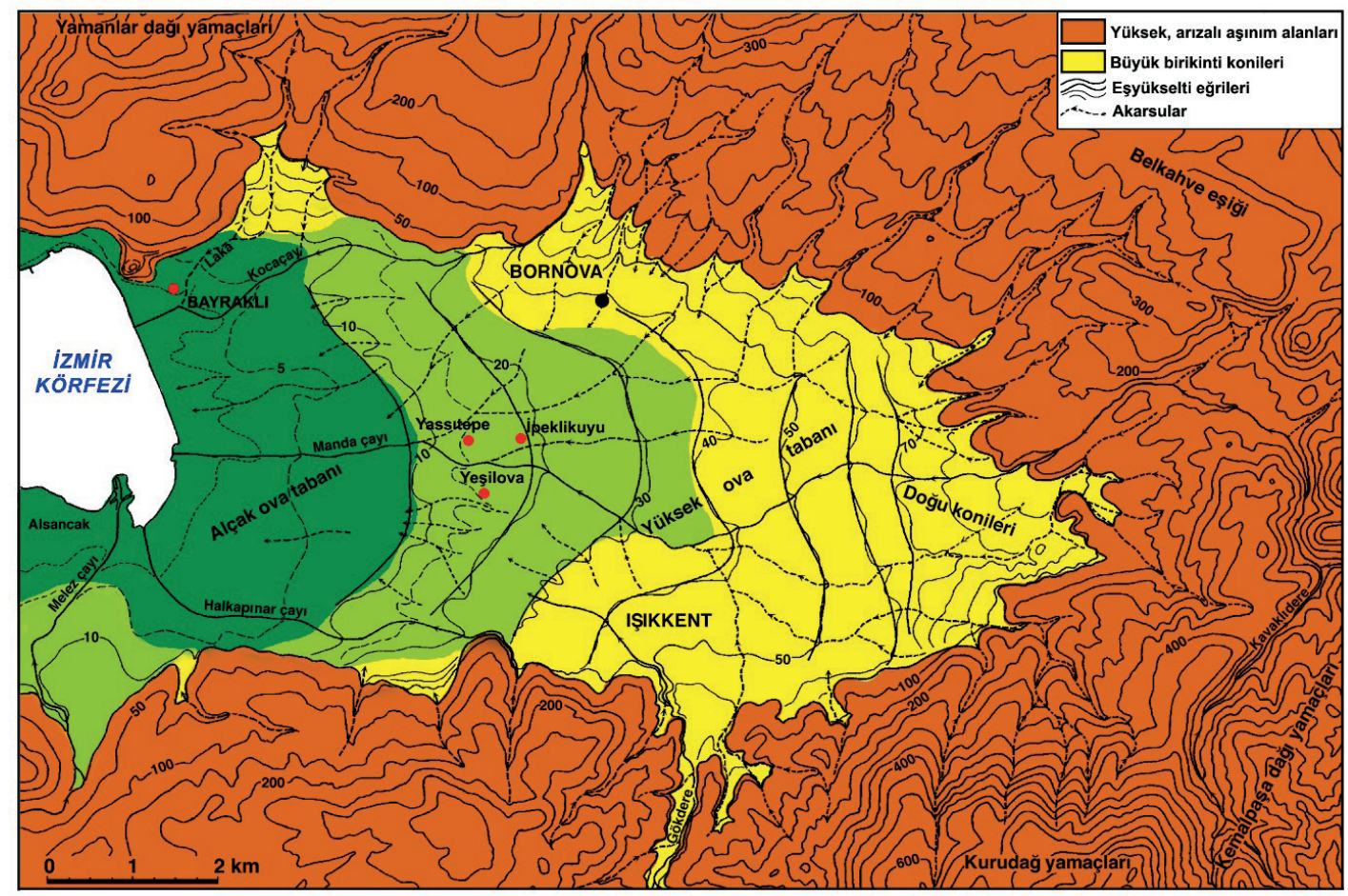

Şekil 6: Bornova Ovasının morfografik birimleri. Kaba taneli kolüvyonlardan oluşan birikinti koni ve yelpazelerinin bulunduğu kesimler Yüksek Ova Tabanını, ince taneli alüvyonlar ile tabanında denizel sedimanların yer aldığı kesimler Alçak Ova Tabanını oluşturmaktadır (Kayan, 2000). Deprem daha çok Alçak Ova Tabanındaki binaları yıkmış, hasar vermiştir.

Figure 6: Relief units of Bornova Plain. Coarse-grained colluvial material of alluvial fans form the High Plain Base. Fine-grained alluviums and marine sediments shapes the Low Plain Base (Kayan, 2000). The earthquake mostly destroyed and damaged the buildings on the lower plain.

düzlükler sözü edilen değişmelerden etkilenmiştir. Yükselen deniz seviyesine bağlı olarak kıyı bölgeleri deniz suları altında kalmış; kıyı çizgisi karaya doğru ilerleyerek koy ve körfezler oluşturmuştur. Deniz seviyesi yükselmesinin durduğu son 6000 yıllık dönemde ise; bu alanlar, akarsuların taşıdığı sedimanlarla doldurulmuş ve kıyı düzlükleri ile deltalar şekillenmiştir. Bornova Ovası'nın alçak ova tabanı Holosen'de gerçekleşen transgresyon ve onunla ilişkili doğal çevre değişmelerinden etkilenmiştir. Ovanın bu bölümünü oluşturan alüvyonların sedimantolojik ve stratigrafik özellikleri üzerinde transgresyona bağlı ortam değişimleri belirleyici olmuştur.

\subsection{Alçak Ova Tabanı Dolgularının Alüvyon Stratigrafisi}

Bornova Ovası'nda yapılan delgi sondaj yöntemine dayalı çalışmalar (Karadaş, 2012; Karadaş, 2014; Öner, Vardar, Karadaş ve İlhan, 2019) Holosen Transgresyonu sirasinda yükselen denizin GÖ. 6000 yıl öncesinde ilerleyerek Bornova Ovası kıyılarına ulaştığını ve deniz sularının bugünkü kıyı çizgisine göre $2 \mathrm{~km}$ kadar iç kesimlere sokulduğunu göstermiştir (Şekil 7). $\mathrm{Bu}$ dönemde alçak ova tabanında alüvyon birikimi ve şekillenme süreçleri üzerinde transgresyon ile gerçekleşen ortam değişmeleri belirleyicidir. Buna göre alçak ova tabanını oluşturan alüvyonlar temelde transgresyon öncesi karasal sedimanlar, Orta Holosen denizel sedimanlar ve genç flüvyal sedimanlar olarak üç gruba ayrılmaktadır.

\section{Transgresyon Öncesi Karasal Sedimanlar}

Holosen transgresyonu öncesinde sedimantasyon karasal koşullar altında devam etmiştir. $\mathrm{Bu}$ dönemde ova tabanında birikmiş olan sedimanlar, mevsimsel akışlı derelerin çevredeki yüksek alanlardan ve birikinti konisi ile yelpazelerinden aşındırarak getirdiği materyalleri ova tabanında biriktirmesiyle oluşmuştur. Bu dolgular Bornova Ovası'nın aşağı bölümünde, bugünkü ova yüzeyinden aşağıda, Orta Holosen denizel sedimanları altında yer alır. Genel olarak, kırmızı-kahverengi renkli bu dolgular nispeten pekişmiş ve kötü boylanmalıdır. Silt çamuru içinde ince-orta-kaba kum ve az çakıllar içeren tane boyu özellikleri göstermektedir (Karadaş, 2012).

\section{Orta Holosen Denizel Sedimanlar}

Holosen transgresyonu sirasinda deniz suları transgresyon öncesi karasal dolgular üzerinde ilerlemiş ve ovanın kıyıya yakın bölümleri bu sırada yükselen deniz suları altında kalmıştır. 


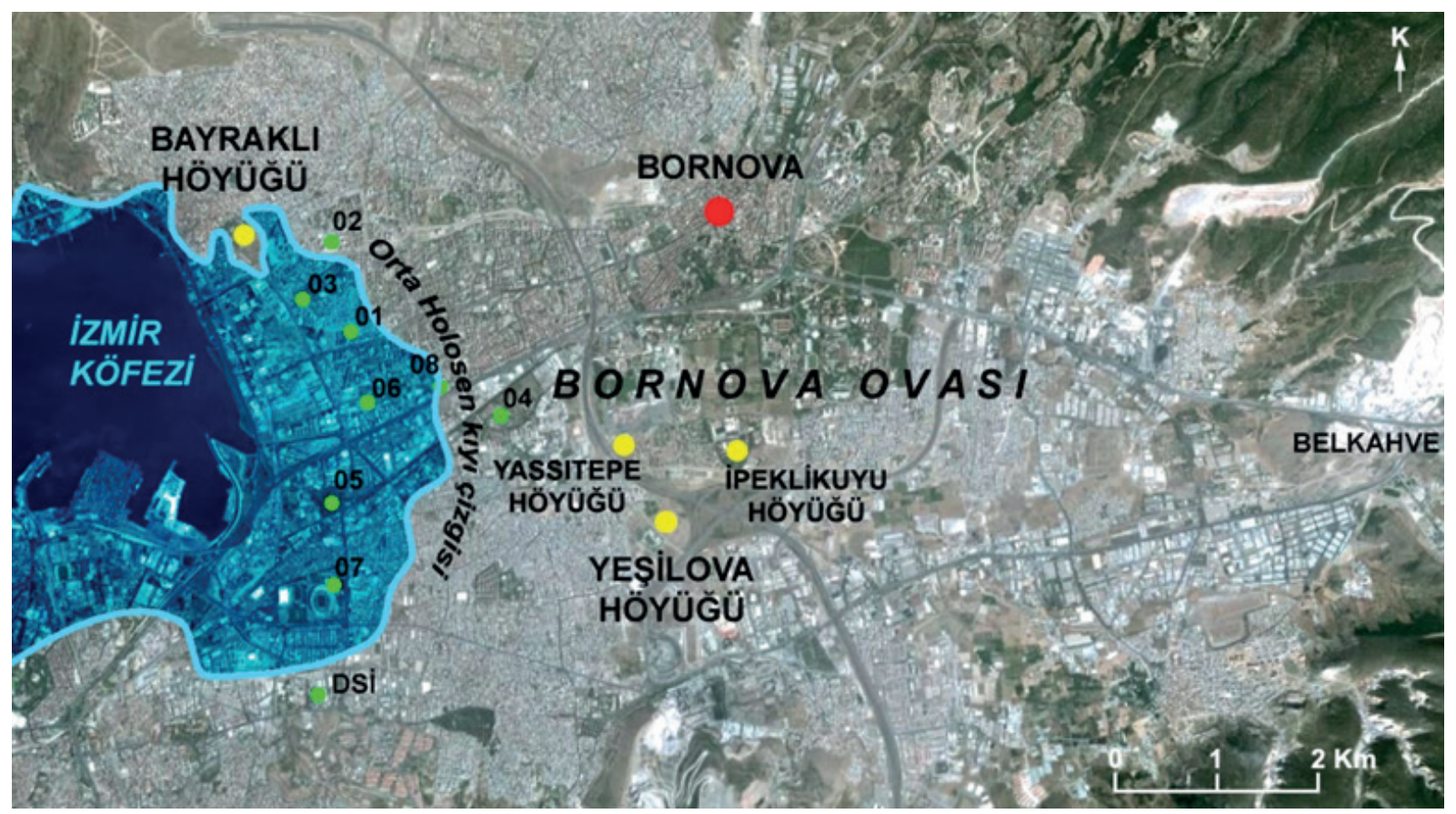

Şekil 7: Bornova Ovası'nda Orta Holosen'de kıyı çizgisinin rekonstrüksiyonu (Karadaş, 2014).

Figure 7: Reconstruction of the Mid-Holocene coastline in the vicinity of Bornova Plain (Karadaş, 2014).

Orta Holosen'den itibaren Bornova kıyılarında sedimantasyon süreçleri denizin doldurulması şeklinde gelişmiştir. Nitekim transgresyon öncesi karasal birikimlerin üzeri yer yer 10 metreye ulaşan kalınlıkta denizel sedimanlar ile örtülmektedir (Şekil 8 ve Şekil 9). Denizel sedimanlar tabanda homojen olmayan silt, kaba-orta-ince kum ve granüller ile başlamakta; karadan taşınan unsurların özelliklerindeki değişmeler ve deniz tabanındaki derinlik koşullarındaki farklılıklar nedeniyle yatay doğrultuda kısa mesafelerde birbirinden farklı özellikler göstermektedir. Çevredeki yüksek kütlelere yakın olan bölümlerde denizel sedimanlar nispeten kaba taneli unsurlardan oluşmaktadır, öte yandan ovanın orta bölümünde denizel sedimanları oluşturan unsurların tane boyları incedir. Bununla birlikte denizel sedimanların tane boyutu dikey doğrultuda da farklılaşmaktadır. Derinlik koşullarındaki değişmelere bağlı olarak alt seviyelerinde kaba tekstür ile başlayıp üste doğru incelmektedir. Denizel birimler tane boyutu değişmekle birlikte genelde iyi yıkanmamış, silt, kil ve temiz kum ardalanmalıdır. Bornova Ovası'nın kıyı kesiminin önemli bir özelliği de yüksek taban suyu seviyesidir. Nitekim ovanın alçak tabanında su seviyesi genel olarak yüzeyden birkaç metre aşağıda yer alır. Tane boyutu ve taban suyu özellikleri nedeniyle denizel sedimanlar, yer yer oldukça gevşek, suya doygun ve balçık karakterlidir. Denizel sedimanların bu özellikleri Orta Holosen'de buraya sokulan denizde düşük enerjili bir su ortamının etkin olduğunu göstermektedir.

\section{Genç Flüvyal Örtü}

Orta Holosen denizel birimler, Geç Holosen'de flüvyal sedimanlar ile örtülmüştür. Denizel ortamdan flüvyal koşullara geçiş sırasında, kıyı çizgisi geri çekilirken kıyı gerisinde bataklıklar oluşmuştur. Genç flüvyal sedimanların tane boyu, tabanda silt - ince kum ile başlayarak üst seviyelere doğru silt orta kum - kaba kum ve granül ağırlıklıdır. Denizel sedimanların üzerini kıyı bölümünde kalınlığı birkaç meteyi geçmeyen ince bir örtü olarak örtmektedir.

\section{BULGULAR}

T.C. Çevre ve Şehircilik Bakanlığı deprem hasar tespit çalışmalarına ait veriler değerlendirildiğinde Bayraklı ve Bornova ilçelerinde Sisam Depremi sırasında hasar alan binaların, Bornova Ovası'nın alçak ova tabanında, belli bir bölümde gösterdiği yoğun dağılış dikkat çekmektedir. Nitekim depremde yıkılan ve hasar gören binaların büyük kısmı Ankara caddesinin kuzeyinde İzmir Körfezi ve Çanakkale otoyolu arasında toplanmaktadır (Şekil 10). Körfez kıyılarından doğuya doğru uzanan bu alan Yamanlar Dağı eteklerinden ovaya inen Laka Deresi ve Kocaçay'ın birikinti konilerine doğru uzanmaktadır. Burası aynı zamanda Bayraklı ilçesinin Adalet, Manavkuyu ve Mansuroğlu mahallelerinin tamamı ile Bornova'nın Kazım Dirik mahallesinin bir bölümüne karşılık 


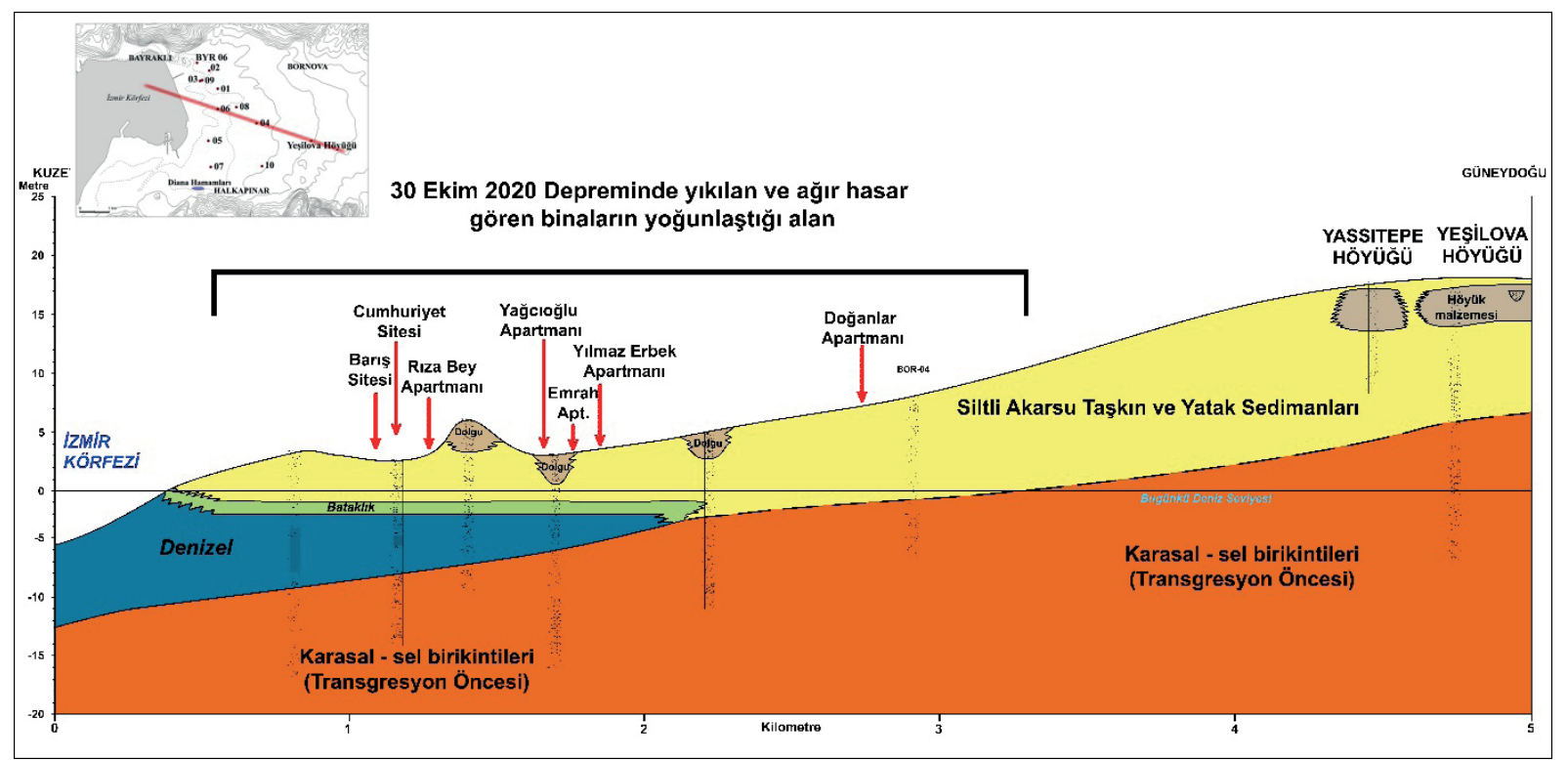

Şekil 8: Bornova Ovası ve ovayı oluşturan alüvyal dolguların D-B doğrultulu stratigrafik-paleocoğrafik boyuna kesiti. Günümüzden 6000 yıl önce Holosen Transgresyonu ile yükselen deniz suları Bornova Ovası'nda bugünkü kıyı çizgisinden 2 km kadar içeriye sokulmuştur. Deniz suları ile istila edilen bu alan günümüzde yoğun yerleşilmiş kent alanıdır. Bu alandaki yapılar 30 Ekim Sisam depreminde ağır hasar almıştır. Depremde yıkılan

binaların 6'sı Orta Holosen denizel sedimanları ve kıyı bataklıklarını kaplayan flüvyal örtü üzerinde bulunmaktadır (Karadaş 2012'den yararlanarak).

Figure 8: Stratigraphical and paleogeographical E-W section of Bornova Plain. The sea waters rising during Holocene Transgression (6000 years ago) were progressed $2 \mathrm{~km}$ inland from the recent coastline on Bornova Plain. This field is the settlement area of Bayraklı District today. The buildings in the area were heavily damaged by Samos Earthquake. Six of the collapsed buildings are located on the fluvial sediments covering the Middle Holocene marine sediments and coastal swamps.

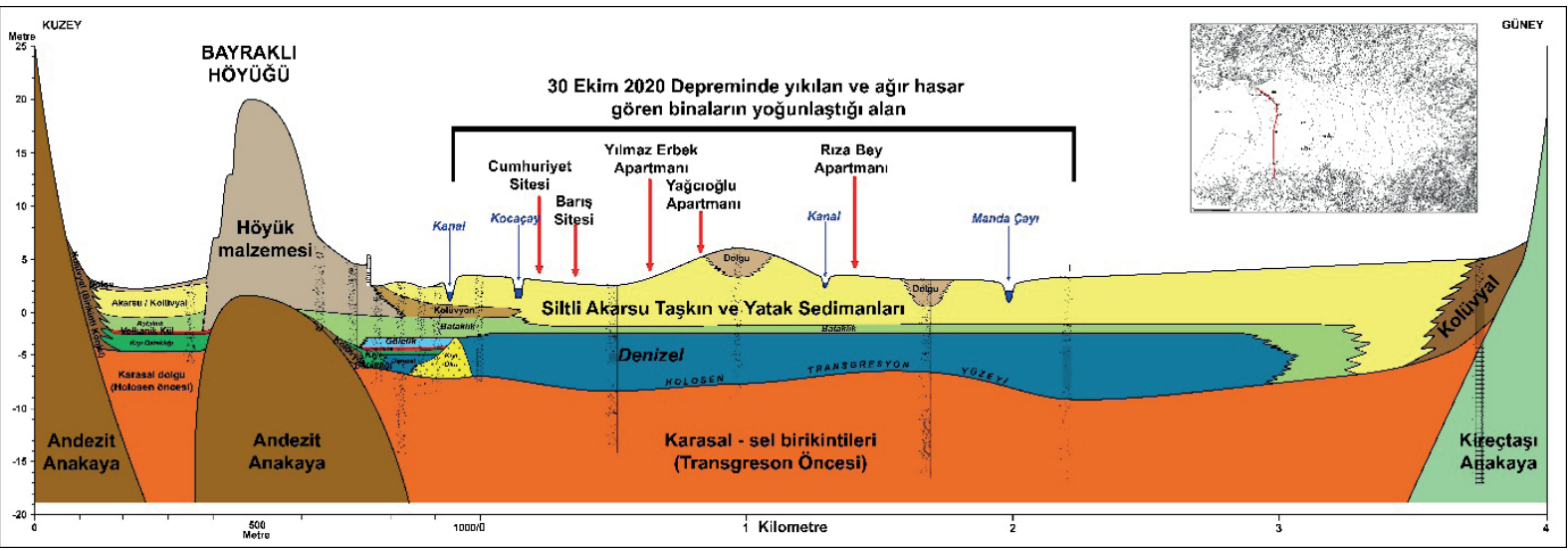

Şekil 9: Bornova Ovası ve ovayı oluşturan alüvyal dolguların K-G doğrultulu stratigrafik-paleocoğrafik enine kesiti. Bornova Ovası'nın kıyıya yakın alçak kesimleri Sisam depreminde ağır hasar almıştır. Depremde yıkılan binaların 6'sı Orta Holosen denizel sedimanları ve kıyı bataklıklarını kaplayan flüvyal örtü üzerinde bulunmaktadır (Karadaş 2012'den yararlanarak).

Figure 9: Stratigraphical and paleogeographical N-S section of Bornova Plain. Lower parts of the Bornova Plain were heavily damaged by Samos Earthquake. Six of the collapsed buildings are located on the fluvial sediments covering the Middle Holocene marine sediments and coastal swamps.

gelmektedir. Sisam Depremi sırasında yıkılan ve can kayıplarının yaşandığı Emrah Apartmanı, Rıza Bey Apartmanı, Doğanlar Apartmanı, Yılmaz Erbek Apartmanı, Yağcılar Sitesi, Barış Sitesi ve Cumhuriyet Sitesi burada yer alır. Yanı sıra, depremde y1kılmayan fakat acil yıkılacaklar listesinde bulunan binalar ile ağır hasar almış binaların birçoğu bu alanda kümelenmiştir.
Depremde yıkılan ve ağır hasar alan binaların bir arada ve birbirine yakın konumda yer alması ovanın bu bölümüne ait alüvyonların özellikleri ile ilişkili olmalıdır.

Bornova Ovası'nda Sisam Depremi nedeniyle hasar alan binaların yoğunlaştığı alan ovanın alçak tabanında yer alır. 


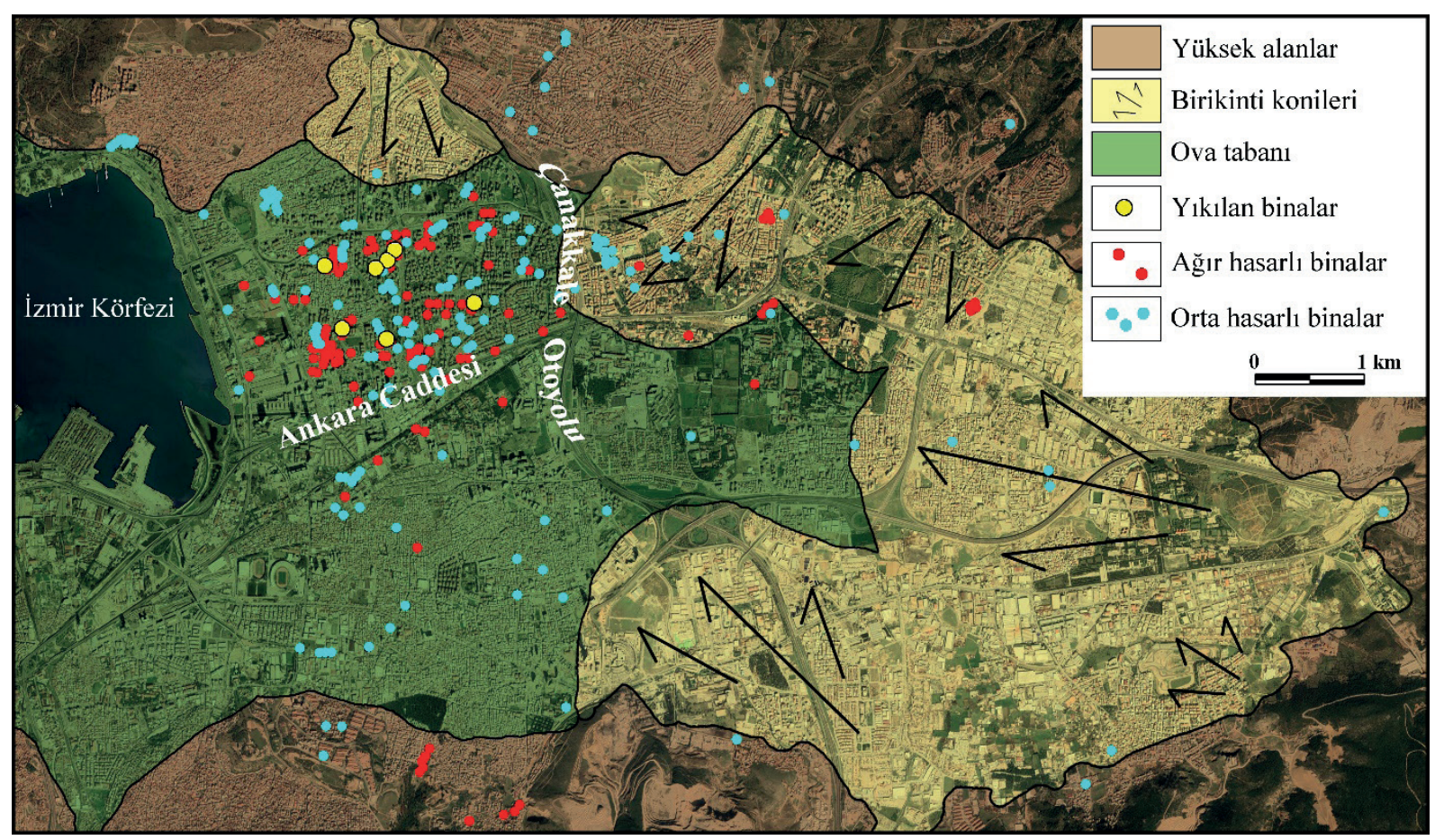

Şekil 10: Sisam Depremi sırasında Bayraklı ve Bornova ilçelerinde orta ve ağır hasar alan binalar ile yıkılan binaların dağılışı. Figure 10: Distribution of buildings damaged during the Samos Earthquake in Bayraklı and Bornova districts.

Buras1, Bornova Ovası'nda Holosen transgresyonunun etkinlik alanına karşılık gelmektedir (Şekil 8). Önceki çalışmalarda ortaya koyulduğu gibi, transgresyonun etkinlik alanında sırasıyla karasal, denizel, flüvyal olmak üzere gerçekleşen fasiyes değişiklikleri, sedimantolojik ve stratigrafik açıdan alüvyonların özelliklerinde dikey ve yatay doğrultuda farklılaşmalar ortaya çıkarmıştır. Diğer bir deyişle, deprem sırasında ağır ve orta hasarlı binaların kümelendiği yerler zemin özellikleri açısından homojen bir karakterde değildir.

Denizel sedimanların gevşek ve balçık seviyeler içermesi ve alçak ova tabanında taban suyu seviyesinin oldukça yüksek olmasına bağlı olarak alüvyal birimlerin suya doygun karakteri deprem riski açısından yapılaşmaya uygun olmayan zemin sınıfında yer almaktadır. Nitekim büyük depremler sırasında suya doygun kumlar ve siltlerin sıvılaşma ve taşıma gücü kaybı yolu ile yapıları önemli hasara uğrattığı bilinmektedir (Erken, Özay, Kaya, Can Ülker ve Elibol, 2004; Taylan, Uysal, Lav ve Erken, 2007). Alparslan (2013), yüzeyden itibaren ilk 15 m ile 20 metre arasında bulunan ve taşıma gücü düşük, suya doygun kumlu, siltli-kumlu ve killi-kumlu birimlerin, özellikle Holosen yaşlı delta ve akarsu birikimleri, sıvılaşmaya karşı daha duyarlı zemin özellikleri sunduğunu ifade etmektedir. Bu açıdan, Bornova Ovası'nın alçak ova tabanı dolguları, yukarıda ifade edilen özellikleri nedeniyle sıvılaşmaya uygun bir zemin sınıfındadır. Bu nedenle Sisam depremi sırasında Bornova ova tabanında sıvılaşma nedeniyle depremin etkileri artmış olmalıdır.

Depremlerin yıkıcı etkilerini artıran bir diğer faktör de havza etkisidir. Havza etkisi temel kayalar üzerinde yer alan pekişmemiş tortul dolgularda deprem dalgalarının yankılanması şeklinde meydana gelir. Yer hareketinin genliğini, frekansını ve süresini önemli ölçüde etkilediği bilinmektedir (Ayoubi, Asimaki ve Mohammdi, 2018). Bornova Ovası'nın alüvyal özelliklerinin deprem riski açısından yarattığı olumsuzluklar yanında ovanın morfolojik özellikleri de Sisam depreminin yıkıcı etkileri üzerinde etkili olmuştur. Bornova Ovası daha önce ifade edildiği gibi doğubatı doğrultulu faylar ile sınırlanmış çöken bir graben tabanıdır. Devlet Su İşleri tarafindan yapılmış zemin sondajlarına ait veriler, bu tektonik çukurluğun derinliği konusunda fikir vermektedir. Nitekim DSİ sondaj verilerine göre ovayı oluşturan pekişmemiş, genç kırıntılı dolgular ova tabanında yer yer 300 metreleri aşan kalınlıklara ulaşmaktadır. Bu kalın detritik istif kuzey ve güneyden Yamanlar Dağı, Kemalpaşa Dağı ve Kalabak Tepe ile çevrilidir (Şekil 3). Bu morfografik özelliklerin, havza etkisi yolu ile deprem dalgalarının etkisini ve depremin süresini artırmış olması muhtemeldir. $\mathrm{Bu}$ durum ise ova tabanında deprem sırasında yaşanan hasarın ve kayıpların boyutunu artırmış olmalıdır.

30 Ekim 2020 Sisam depremi sirasinda Bornova Ovası'nda ağır hasar ve can kayıplarının ortaya çıkmasında, zemin 
özellikleri açısından ovanın depreme uygun olmayan karakterinin yarattığı etkiler şüphesizdir. Ancak, hasar verileri detaylı olarak açılanmamış olsa da, yörede yapılan gözlemler depremden ağır hasarla etkilenen binaların büyük çoğunluğunun yüksek katlı yapılar olduğunu açıkça ortaya koymaktadır (Şekil 2). Özellikle 5 kat ve altındaki binalarda önemli hasar kaydı oluşmamıştır. Bu durum zeminin olumsuz etkilerinin yanı sıra yapılara ait özelliklerin hasar durumunda oldukça etkili bir faktör olduğunu işaret etmektedir.

\section{SONUÇ VE DEĞERLENDİRME}

30 Ekim 2020 Cuma günü saat 14.51 'de Sisam adas1 kuzeyinde deniz tabanındaki eğim atımlı fayın kırılması ile meydana gelen deprem, kuş uçumu $70 \mathrm{~km}$ uzaktaki Bornova Ovası'nda 7 binanın yıkılması ve buna bağlı 117 can kaybı ve çok sayıda ağır ve orta ölçekli bina hasarı ile sonuçlanmıştır. Kayıp ve hasar durumu açısından tüm Batı Anadolu ve Ege Denizi adaları arasında Bornova Ovası depremden en çok etkilenen bölge olmuştur.

Bornova Ovası'nda ovayı oluşturan alüvyal dolguların (alüvyon / kolüvyon ve denizel çamurlar) özelliklerinin deprem hasarı üzerinde etkileri önemlidir. Alçak ova tabanı bölümünde alüvyal birikimin stratigrafik ve sedimantolojik özellikleri, Holosen'de meydana gelen paleocoğrafya koşulları tarafindan belirlenmiştir. Özellikle ovanın kıyıdan birkaç kilometre içeriye kadar olan bölümünde şekillenme üzerinde Holosen transgresyonun etkileri önemlidir. Ovanın bu bölümünde alüvyon stratigrafisinde transgresyona bağlı ortam değişmeleri çeşitlilik yaratmaktadır. Şöyle ki, Bornova Ovası'nın kıyı gerisinde alçak ova tabanını oluşturan Holosen sedimanları altta karasal kırıntılı örtüler ile başlamaktadır. Bu dolgular Orta Holosen transgresyonu öncesinde karasal koşullarda birikmiş kötü boylanmalı ova tabanı dolgularıdır. Bu dolguların üzeri Orta Holosen denizel sedimanları ile örtülmektedir. Denizel sedimanlar, yatay ve dikey doğrultuda tane boyu açısından farklı özellikler sunmaktadır. Denizel sedimanların tane boyutu yer yer kum-silt-kil oranı değişmekle birlikte alt seviyelerde kaba tekstür ile başlayıp üste doğru incelmektedir. Bununla birlikte bu birim, taban topografyasına bağlı olarak değişen kalınlıkta (3 - 10 metre), oldukça gevşek ve suya doygun balçık bir karakterdedir. Denizel sedimanların üzeri, Geç Holosen'de flüvyal sedimanlar ile örtülmüştür. Denizel ortamdan flüvyal koşullara geçiş tedrici gerçekleşmiş ve bu dönemde, kıyı çizgisi geri çekilirken kıyı gerisinde bataklıklar oluşmuştur. Genç flüvyal sedimanların tane boyu, alt seviyelerde silt - ince kum; üst seviyelere doğru silt - orta kum - kaba kum ve granülden oluşmaktadır.
Bornova Ovasını oluşturan alüvyonların özelliklerinde yatay ve dikey doğrultuda görülen değişmeler, Sisam depremi sırasında zemin davranışı açısından depremin etkisini büyütecek sonuçlar yaratmış olmalıdır. Nitekim deprem sırasında yıkılan ve ağır hasar alan binaların büyük bölümünün Orta Holosen denizinin yayılış alanında yer alması tesadüfi değildir. Ovayı oluşturan alüvyonların birikme ortamının ve tane özelliklerinin depremin şiddeti ve yarattı̆̆ı hasar üzerinde etkili olan önemli bir parametre olduğu açıktır.

Bornova Ovas1, Batı Anadolu'nun horst - graben sistemi içinde küçük bir tektonik çukurluk / grabendir. Güneyde İzmir Fayı ve kuzeyde Karşıyaka Fayı ile sınırlanan bu küçük ova tabanı nispeten dirençli Tersiyer volkanitleri ile Mesozoik yaşı fliş fasiyesinde birikmiş tortul kayaçlarla çevrilidir. Bu durum, Yamanlar Dağı'na yakın bölümlerde (Adalet, Manavkuyu Mansuroğlu mahalleri) deprem şiddetinin ve etkisinin havza etkisiyle artmış olduğuna işaret etmektedir. Şöyle ki, Kuşadası Körfezi'nden yayılan deprem dalgaları Bornova Ovası'nın yüzlerce metre kalınlıklara ulaşan kırıntılı malzemesi (alüvyal, kolüvyal ve denizel sedimanları) içinde ve özellikle Yamanlar Dağı'nın dirençli volkanik kayaçlardan yapılı kütlesi önünde daha fazla süre oyalanmış olmalıdır.

Bornova Ovası'nın alçak ova tabanında yeraltı suyu seviyesi yüksektir ve özellikle kıyıya yakın bölümlerde yüzeye birkaç metre yakın bulunmaktadır. Ovayı oluşturan alüvyal dolgular suya doygundur. $\mathrm{Bu}$ koşullar altında Bornova Ovası'nda depremin etkileri açısından havza etkisi yanında ovanın suya doygun dolguları üzerinde sıvılaşmanın da önemli bir tehdit olarak deprem sırasında deprem dalgalarının etkisini daha da artırmış olmalıdır. Nitekim Bornova Ovası'nda, deprem anında yıkılan ve 117 can kaybının yaşandığ binalar, bütünüyle alçak ova tabanındaki denizel çamurlar ile suya doygun ince taneli alüvyal sedimanlar üzerinde bulunmaktadır.

Yukarıda belirtilen zemin ile ilgili olumsuzluklara ek olarak, inşaat malzeme ve yapı tekniği açısından kusurlu olduğu ifade edilen binaların, Bornova Ovası'nın zemin niteliği bakımından kalın dolgular oluşturan pekişmemiş kırıntılı birikimleri üzerinde yer alması deprem sırasında yaşanan olumsuzlukları artırmıştır. Öte yandan, geçmiş yıllarda yakın çevrede meydana gelmiş depremlerin ovadaki yapılarda ve binalarda çeşitli hasarlar yaratmış olduğu muhakkaktır. Bu durumun göz ardı edilmesi de öncekilerden daha büyük olan Sisam Depremi ile yıkılmalarına yol açmış olmalıdır. Deprem anında yıkılan binaların büyük bir çoğunluğunun son deprem yönetmeliğinden önce inşa edilmiş olması da hasar durumunun artmasında etkili olmuştur. 
Tektonik bakımdan oldukça aktif olan İzmir Körfezi ve çevresinde tarih boyunca şiddetli depremler meydana gelmiş ve tarihsel dönemlerden beri bu yıkıcı depremler nedeniyle bölgede can ve mal kaybı olmuştur. Deprem potansiyeli açısından risk oluşturan İzmir ve Karşıyaka faylarının aktivitesi konusunda veriler sınırlı olmakla birlikte deprem kayıtları İzmir fayının yakın dönemde etkin olduğunu göstermektedir. Dolayısıyla İzmir çevresinde meydana gelebilecek büyük depremler ve bu depremlere bağlı ortaya çıkacak tehlikeler açısından zemin özelliklerinin etraflıca ortaya koyulması büyük bir gerekliliktir. Nitekim İzmir kent nüfusunun büyük kısmı Bornova Ovası ve İzmir Körfezini çevreleyen alüvyal düzlüklerde (Karşıyaka Deltas1, Gediz deltası, Meles Deltası ve Balçova düzlüğü) yaşamaktadır. Öte yandan bu alanlar kentin yüksek yapılaşmış ve yapılaşması devam eden alanlarıdır. Özellikle son yıllarda Bornova Ovası'nın hemen kıyı gerisindeki bölümü çok yüksek katlı binaların inşa edildiği bir bölgeye dönüşmektedir. $\mathrm{Bu}$ açıdan Bornova Ovası dâhil körfezi çevreleyen alüvyal alanları oluşturan alüvyonların özelliklerinin ve olası bir depreme karşı gösterecekleri tepkilerin belirlenmesi önem taşımaktadır.

Hakem Değerlendirmesi: Dış bağımsız.

Çıkar Çatışması: Yazarlar çıkar çatışması bildirmemiştir.

Finansal Destek: Yazarlar bu çalışma için finansal destek almadığını beyan etmiştir.

Peer-review: Externally peer-reviewed.

Conflict of Interest: The authors have no conflict of interest to declare.

Grant Support: The authors declared that this study has received no financial support.

\section{KAYNAKÇA/REFERENCES}

AFAD (Deprem Dairesi Başkanlığı). (2020). 30 Ekim 2020 Sisam Adası (İzmir Seferihisar Açıkları) Mw 6.6 Depremi Raporu, https:// deprem.afad.gov.tr/downloadDocument?id=2065

Akdeniz, N., Konak, N., Öztürk, Z. ve Çakır, M. H. (1986). İzmirManisa Dolaylarının Jeolojisi. MTA Rapor No: 7929, Ankara.

Alparslan, N. (2013). Zemin Sıvılaşması ve Mekanizması. Batman Üniversitesi Yaşam Bilimleri Dergisi, 3(2), 67-89.

Ayoubi, P., Asimaki, D., Mohammdi, K. (2018). Basin Effects in Strong Ground Motion: A Case Study from the 2015 Gorkha, Nepal Earthquake. Geotechnical Earthquake Engineering and Soil Dynamics V, Austin, Texas. 288-296. (https://doi. org/10.1061/9780784481462.028).

Benjamin, J., Rovere, A., Fontana, A., Furlani, S., Vacchi, M., Inglis, R. H., Galili, E., et al. (2017). Late Quaternary sea-level changes and early human societies in the central and eastern Mediterranean Basin: an interdisciplinary review. Quaternary International, 449, 29-57.
Brückner, H., Vött, A., Schriver, M., Handl, M. (2005). Holocene Delta Progradation in the Eastern Mediterranean - Case Studies in Their Historical Context. Méditerranée, 104(2005/1-2), 95-106.

Brückner, H., Kelterbaum, D., Marunchak, O., Porotov, A., Vött, C. (2010). The Holocene Sea Level Story since 7500 BP- Lessons from the Eastern Mediterranean the Black and the Azov Seas. Quaternary International, 225(2), 160-179.

Erken, A., Özay, R., Kaya, Z., Can Ülker, M.B., Elibol, B. (2004). Depremler Sırasında Zeminlerin Sıvılaşması ve Taşıma Gücü Kayıları. Türkiye Mühendislik Haberleri, 431(2004/3), 20-26.

Erinç, S, Bilgin, T., Bener, M., Sungur, K., Erer, S., Göçmen, K. (1970). 28 Mart 1970 Gediz depremi : Tatbikî jeomorfolojik Etüd. İstanbul Üniversitesi Edebiyat Fakültesi Yayınları No: 1520.

Erinç, S, Bener, M., Sungur, K., Göçmen, K. (1971). 12 Mayıs 1971 Burdur depremi : Tatbikî jeomorfolojik Etüd. İstanbul Üniversitesi Edebiyat Fakültesi Yayınları No: 1520.

Fleming, K., Johnston, P., Zwartz, D., Yokoyama, Y., Lambeck, K., Chappell, J. (1998). Refining the Eustatic Sea-Level Curve Since the Last Glacial Maximum Using Far-and İntermediate-Field Sites. Earth and Planetary Science Letters, 163, 327-342.

Gunay, S., Mosalam, K., Archbold, J., Dilsiz, A., Djima, W., Gupta, A., Javadinasab H. S., Hassan, W., Heresi, P., Morales-Beltran, M. Muin, S., Robertson, I., Romao, X., Kijewski-Correa, T. (2020). Preliminary Virtual Reconnaissance Report (Pvrr). Aegean Sea Earthquake. Report number: PRJ-2953, DOI 10.17603/ds2-kmxdgj50.

Karadaş, A. (2012). Bornova Ovasının Fiziki Coğrafyası (Basılmamış Doktora tezi). Ege Üniversitesi Sosyal Bilimler Enstitüsü, İzmir.

Karadaş, A. (2014). Bornova Ovası (İzmir) Holosen Paleocoğrafyası ve Kıyı Çizgisi Değişmeleri. Ege Coğrafya Dergisi, 23(2).

Kayan, İ. (1991). Holocene Geomorphic Evolution of the Beşik Plain and Changing Environment of Ancient Man. Studia Troica, 1, 7992, Philipp von Zabern, Mainz am Rhein, Germany.

Kayan, İ. (1997). Türkiye'nin Ege ve Akdeniz Kıyılarında Deniz Seviyesi ve Kıyı Çizgisi Değişmeleri. Türkiye’nin Kıyı ve Deniz Alanları 1. Ulusal Konferansı Bildiriler Kitabı, Ankara.

Kayan, İ. (1999). Holocene Stratigraphy and Geomorphological Evolution of the Aegean Coastal Plains of Anatolia. Quaternary Science Reviews, 18, 541-548.

Kayan, İ. (2000). İzmir Çevresinin Morfotektonik Birimleri ve Alüvyal Jeomorfolojisi. Batt-Anadolu'nun Depremselliği Sempozyumu (BADSEM) 2000 Bildiriler Kitabl, 103-111, İzmir.

Kayan, İ. (2012). Kuvetarner'de Deniz Seviyesi Değişmeleri. Kuvaterner Bilimi (Ed. N. Kazanc1, A. Gürbüz), Ankara Üniversitesi Yay. No: 350, Ankara, 59-78.

Lambeck, K., Purcell, A. (2005). Sea-Level Change in the Mediterranean Sea since the LGM: Model Predictions for Tectonically Stable Areas. Quaternary Science Reviews, 24, 1969-1988.

Lambeck, K., Rouby, H., Purcell, A., Sun, Y., Sambridgea, M. (2014). Sea level and global ice volumes from the Last Glacial Maximum to the Holocene. PNAS., 111(43), 15296-15303. 
METU/EERC, (2020). The October 30, 2020 İzmir-Seferihisar Offshore (Samos) Earthquake $(M w=6.6)$ Reconnaissance Observations And Findings. REPORT NO: METU/EERC 2020-03

https://eerc.metu.edu.tr/en/system/files/documents/Izmir\%20 Earthquake\%20Report.pdf

Öner, E., ve Kayan, İ. (2005). İzmir Körfezi Kıyılarında Alüvyon Birikimi ile Karşıyaka ve Bayraklı Kıyılarının Şekillenmesi. Karşıyaka Kültür ve Çevre Sempozyumu Bildiriler Kitabı, 8-22, İzmir.

Öner, E., Vardar, S. (2018). Gediz Deltası Paleocoğrafyasında Panaztepe'nin Limanını Bulma Umudu. Journal of Awareness, 3(5), 1-18.

Öner, E., Vardar, S., Karadaş, A., İlhan, R. (2019). Bayraklı Höyüğünde (Smyrna-Tepekule) 2018 Y11 Paleocoğrafya ve Jeoarkeoloji Araştırmaları (İzmir). 35.Arkeometri Sonuçları Toplantısı Bildiriler Kitabi. 217-238.

Papadimitriou, P., Kapetanidis, V., Karakonstantis, A., Spingos, I., Kassaras, I., Sakkas, V., Kouskouna, V., Karatzetzou, A., Pavlou, K., Kaviris, G., Voulgaris, N. (2020). Preliminary Report on the $M$ $w=6.9$ Samos Earthquake of 30 October 2020. DOI 10.13140/ RG.2.2.28729.60002.

Peltier, W. R. (2002). On eustatic sea level history: Last Glacial Maximum to Holocene. Quaternary Science Review 21, 377-96.

Perissoratis, C., Conispoliatis N. (2003). The Impacts of Sea-Level Changes During Latest Pleistocene and Holocene Times on the Morphology otThe Ionian and Aegean Seas (SE Alpine Europe). Marine Geology, 196, 145-156.

Sarı, B. (2018). Beytitepe Kireçtaşı'nın (Bornova Fliş Zonu) Gökdere Alanında (İzmir, Batı Türkiye) Planktonik Foraminifer Biyostratigrafisi ve Mikrofasiyes Özellikleri, Dokuz Eylül Üniversitesi-Mühendislik Fakültesi Fen ve Mühendislik Dergisi, 20(59), 576-594.

Sözbilir, H., Uzel, B., Sümer, Ö., İnci, U., Ersoy, E.Y., Koçer, T. (2008). D-B Uzanımlı İzmir Fayı ile KD-Uzanımlı Seferihisar Fayı'nın Birlikte Çalıştığına Dair Veriler: İzmir Körfezi’ni Oluşturan Aktif Faylarda Kinematik ve Paleosismolojik Çalışmalar, Batı Anadolu, Türkiye. Türkiye Jeoloji Bülteni, 51(2), 91-114.
Sözbilir, H., Tatar, O. Akgün, M., Ankaya Pamukçu, O., Baba, A., Özden, G., Özçelik, Ö., Çırmık, A., Utku, M., Softa, M., Uzelli, T., Eski, S., Özdağ, Ö., Çakır, R., Tepe, Ç., Evlek, D. (2020). 30 Ekim 2020 Sisam (Samos) Depremi (Mw: 6,9) Değerlendirme Raporu. DOI 10.13140/RG.2.2.33392.48644.

Şenol, D. (2003). Gediz Depreminin Düşündürdükleri, Kırıkkale Üniversitesi Sosyal Bilimler Enstitüsü Dergisi 3.

Taylan, Z.N., Uysal, H., Lav, M.A., Erken, A. (2007). Sıvılaşma ve Taşıma Gücü Kaybı Sonucu Oluşan Oturmaları Kapsayan Vaka Analizi. Altıncı Ulusal Deprem Mühendisliği Konferansı, 16-20 Ekim 2007 Bildiriler Kitabl, s. 471-482.

Toprakçı, H., Ekizler, T. (2020, Aralık 06). İzmir'de depremin ardından acil y1k1lacak 71 binadan 67'sinin yıkımı tamamland1. AA Haber Ajansl. https:/www.aa.com.tr/tr/turkiye/izmirde-depreminardindan-acil-yikilacak-71-binadan-67sinin-yikimitamamlandi/2067256

Turoğlu, H. (2004). Zemin Sıvılaşmasının 17 Ağustos 1999 Depreminde Adapazarı'ndaki Hasara Etkisi. İstanbul Üniversitesi Edebiyat Fakültesi Coğrafya Bölümü Coğrafya Dergisi 12, 63-74.

Uzel, B., Sözbilir, H., Özkaymak, Ç. (2012). Neotectonic Evolution of an Actively Growing Superimposed Basin in Western Anatolia: The Inner Bay of İzmir, Turkey, Turkish Journal of Earth Sciences, 21(4), 439-471.

Vardar, S., Öner, E., İlhan, R. (2017). Bağlararası Höyügü Çevresinde Paleocoğrafya ve Jeoarkeoloji Araştırmaları (Çeşme- İzmir). Türkiye Jeoloji Bülteni, 60, 589-614.

Vardar, S., İlhan, R., Öner, E., (2020). Teos Antik Yerleşimi Çevresinde Paleocoğrafya-Jeoarkeoloji Araştırmalarının İlk Sonuçları (Seferihisar-İzmir). Coğrafya Dergisi - Journal of Geography, 40, 323-338.

Waelbroeck C., Labeyrie L., Michel E., Duplessy J. C., McManus J. F., Lambeck K., Balbon E., Labracherie M. (2002). Sea- Level and Deep Water Temperature Changes Derived from Benthic Foraminifera Isotopic Records. Quaternary Science Reviews, 21, 295-305. 
